\title{
STRATEGI PENGEMBANGAN HARGA DIRI ANAK USIA DINI
}

\author{
Dwi Hastuti \\ PG PAUD FKIP UAD Yogyakarta \\ E-mail: d.hastuti28@yahoo.com
}

\begin{abstract}
Abstrak
Masa usia dini adalah saat yang paling tepat untuk menanamkan karakter dan kepribadian anak. Salah satu aspek kepribadian yang penting untuk dikembangkan adalah harga diri. Seorang anak dengan harga diri yang tinggi mampu menampilkan dirinya sebagai pribadi yang menyenangkan, mudah menyesuaikan diri dengan lingkungan, mandiri, aktif, berani mengemukakan pendapat, dan percaya diri.

Tulisan ini bermaksud untuk membahas tentang strategi pengembangan harga diri anak serta upaya-upaya konstruktif yang dilakukan bersama agar harga diri anak dapat berkembang dengan baik. Tulisan ini merupkan kajian literatur untuk menemukan formula baru tentang strategi pengembangan harga diri anak usia dini. Pembentukan harga diri merupakan sebuah proses yang berkesinambungan. Harga diri yang telah terbentuk pada usia dini akan memberikan pengaruh yang sangat signifikan terhadap perilaku kehidupan anak di kemudian hari. Sedemikian pentingnya pengembangan harga diri bagi setiap individu, maka perlu adanya kerjasama yang sinergis antara guru di sekolah dan orangtua.
\end{abstract}

Kata Kunci: strategi, harga diri, anak usia dini

\begin{abstract}
Early childhood is the bestperiod to develop children's characters and personalities. One of the important aspect needs to develop is self esteem. Children with high self esteem may perform themselves as an exciting, adaptive, independent, active, and confident children

This article explains the strategies to develop children's self esteem and the constructive efforts to make them grow properly. This paper is a review of the literature to find a new formula on the development strategy of self-esteem of early childhood. The formation of self-esteem is a continuous process. Esteem that has been formed at an early age will give a very significant influence on the behavior of children's lives in the future. So important development for the dignity of every individual, the need for synergistic cooperation between teachers in the school and parents.
\end{abstract}

Key words: strategy, self esteem, early childhood 


\section{Pendahuluan}

Keberhasilan pada masa kanak-kanak menjadi landasan bagi keberhasilan pendidikan seseorang pada jenjang berikutnya. Usia dini disebut sebagai golden age atau usia emas, artinya apabila seorang anak mendapatkan pendidikan yang tepat, maka ia akan memiliki kesiapan belajar yang baik sebagai salah satu kunci utama keberhasilan belajar pada jenjang berikutnya.

Sangat menyedihkan ketika ditemukan bukti yang menunjukkan bahwa harga diri anak usia sekolah dasar lebih rendah daripada saat usia taman kanak-kanak. Perhatian pendidik dan masyarakat umumnya terhadap perkembangan anak lebih banyak mengarah pada aspek kognitif dan psikomotorik anak. Hal ini pun ditengarai terjadi pada para pendidik dan pengelola lembaga pendidikan khususnya satuan pendidikan berupa sekolah formal. Sekolah sebagai tempat mempersiapkan anak untuk dapat hidup lebih baik di masa depannya menyuguhkan materi/pelajaran yang lebih mengedepankan perkembangan kognitif anak. Padahal, mengarungi kehidupan tidak sematamata bermodalkan kecerdasan akademik. Lebih dari itu, sisi emosional seorang individu bahkan dapat memegang peran lebih dominan daripada intelegensi. Sejalan dengan tujuan sekolah untuk mengembangkan kompetensi anak dari berbagai macam aspek, perlu disadari bahwa terdapat beberapa sisi psikologis yang hendaknya juga ditumbuhkan dalam proses pembelajaran di kelas, yaitu pengendalian diri, kebutuhan berprestasi, penguasaan, serta harga diri (self esteem).

Tulisan ini membahas tentang beberapa solusi untuk memecahkan permasalahan tentang pengembangan harga diri anak, dengan harapan anak akan berkembang menjadi individu yang mampu menghadapi tantangan kehidupannya di masa yang akan datang.

\section{PEMBAHASAN}

\section{Pengertian Harga Diri}

Aliran psikologi yang banyak membicarakan tentang pentingnya self esteematau harga diri adalah humanisme, terutama Rogers dan Abraham Maslow. Rogers membagi konsep diri menjadi tiga bagian, yaitu: (1) ideal self, (2) self image, dan (3) self esteem. Self image atau citra diri adalah persepsi kita terhadap diri kita. Sedangkan penilaian terhadap diri kita, baik-buruk, pintar-bodoh, disebut self esteem. Orang yang memiliki self esteem yang optimal disebut ideal self atau diri yang ideal. Tinggi rendahnya self esteem tergantung pada jarak antara diri yang ideal (ideal self) dan citra diri (self image). Apabila jaraknya panjang, harga dirinya rendah. Tapi bila jaraknya pendek, harga dirinya tinggi. (Musbikin, 2004: 96)

Johnson\& Jonson (1991) berpendapat bahwa bicara tentang harga diri, berarti bicara mengenai satu aspek dalam konsep diri yang menentukan akan berkembang menjadi individu 
seperti apakah anak-anak generasi bangsa kelak. Konsep diri positif akhirnya akan membentuk harga diri yang kuat. Harga diri merupakan penilaian tentang keberartian diri dan nilai seseorang yang didasarkan atas proses pembuatan konsep dan pengumpulan informasi tentang diri beserta pengalamannya.

Harter dalam Papalia (2009: 383) mengatakan bahwa seperti juga dengan konsep diri itu sendiri, harga diri pada masa kanakkanak awal cenderung bersifat semua atau tidak sama sekali; 'saya baik' atau 'saya jahat'. Baru pada masa kanak-kanak tengah evaluasi personal mengenai kompetensi dan kemampuan berdasarkan internalisasi standar orangtua atau sosial anak menjadi penting dalam membentuk atau mempertahankan perasaan keberhargaan diri.

Dalam beberapa literatur, juga digunakan istilah self-perception yang merupakan kumpulan dari keyakinan dan perasaan yang anak miliki terhadap dirinya sendiri. Penilaian ini sangat berpengaruh pada perkembangan emosi, perilaku dan penyesuaian diri anak di lingkungan sosial. Anak-anak biasanya menilai dirinya masih dalam bentuk sederhana, contohnya "Aku sudah bisa memakai baju sendiri" atau "Aku punya teman banyak". Setinggi apa harga diri anak amat sangat berpengaruh pada masa prasekolah dimana mereka mulai belajar menguasai ketrampilan baru.

Stuart dan Sundeen (1991) mengatakan bahwa harga diri adalah penilaian individu terhadap hasil yang dicapai dengan menganalisa seberapa jauh perilaku memenuhi ideal dirinya. Dapat diartikan bahwa harga diri menggambarkan sejauhmana individu tersebut menilai dirinya sebagai orang yang memiliki kemampuan, keberartian, berharga, dan kompeten. Sementara menurut Burns (1993: 7) harga diri adalah perasaan bahwa 'diri' itu penting dan efektif, dan melibatkan pribadi yang sadar akan dirinya sendiri.

Menurut Gilmore dalam Papalia (2009: 174) berpendapat bahwa, “....self esteem is a personal judgement of worthiness that is a personal that is expressed in attitude the individual holds toward himself. Pendapat ini menjelaskan, harga diri merupakan penilaian individu terhadap kehormatan dirinya, yang diekspresikan melalui sikap terhadap dirinya. Demikian juga, harga diri merupakan penilaian individu terhadap dirinya sendiri yang sifatnya implisit dan tidak diverbalisasikan.

Menurut pendapat beberapa ahli tersebut, maka dapat disimpulkan bahwa harga diri adalah penilaian individu terhadap kehormatan diri, melalui sikap terhadap dirinya sendiri yang sifatnya implisit dan tidak diverbalisasikan dan menggambarkan sejauh mana individu tersebut menilai dirinya sebagai orang yang memiliki kemampuan, keberartian, berharga, dan kompeten.

Menurut Erikson dalam Diane E.Papalia (2008: 485) faktor penentu harga diri adalah pandangan anak akan kemampuan kerja 
produktif mereka. Isu yang harus dipecahkan pada masa kanak-kanak pertengahan adalah industri vs inferioritas. "Kebijakan" yang berkembang bersama resolusi krisis ini adalah kompetensi (competence), pandangan yang memandang diri sendiri mampu menguasai keterampilan dan menuntaskan tugas.

Coopersmith (1967: 71) menyatakan bahwa ciri-ciri anak dengan harga diri tinggi menunjukkan perilaku-perilaku seperti mandiri, aktif, berani mengemukakan pendapat, dan percaya diri. Sedangkan seseorang dengan harga diri yang rendah menunjukkan perilaku seperti kurang percaya diri, cemas, pasif, serta menarik diri dari lingkungan.

Anak dengan harga diri yang tinggi cenderung mengatribusikan kegagalan atau kekecewaan pada faktor di luar diri mereka atau pada kebutuhan untuk berusaha lebih keras. Jika pada awalnya gagal atau ditolak, mereka tetap gigih mencoba berbagai cara baru sampai menemukan cara yang berhasil. (Papalia, 2009: 384)

Harga diri yang sehat dapat menjadi tameng bagi anak untuk menghadapi tantangan dalam hidupnya. Anak yang berpandangan positif tentang dirinya akan mudah mengatasi konflik dan tidak mudah tepengaruh oleh hal-hal negatif. Mereka akan tumbuh menjadi individu yang optimis. Di sisi lain, anak-anak yang berpandangan negatif atau rendah pada diri mereka sendiri akan menemui rintangan dalam mengatasi masalah, menjadi pasif, menarik diri, mudah frustrasi dan tidak bahagia. Ketika dihadapkan tantangan, mereka mudah sekali untuk bilang "tidak bisa". Namun anak yang terlalu memandang tinggi dirinya juga tidak berdampak baik. Mereka akan cenderung merasa paling baik, tidak mau dikalahkan dan meremehkan orang lain. Anak semacam ini akan sulit untuk menerima kekalahan dan sulit beradaptasi yang membatasi keleluasaannya. Jadi harga diri yang sehat adalah harga diri yang dapat membekali anak untuk berperilaku sesuai dengan tuntutan dimana pun dia berada, tidak kurang atau berlebihan.

Menurut Phelan (2009: 237) harga diri bukanlah sejenis proyek untuk membuat anakanak merasa diri lebih baik, apapun keadaan mereka. Jika kualitas tertentu menjadi kekurangan/kelemahan pada hidup seseorang, maka harga diri positif tidak bisa diperoleh dalam waktu seketika. Harga diri didasarkan pada kenyataan, bukan pada tipu muslihat.

\section{Komponen Harga Diri}

Menurut Felker (1974), komponen harga diri adalah:

a. Feeling of belonging, yaitu perasaan individu bahwa dirinya merupakan bagian dari suatu kelompok dan individu tersebut diterima oleh anggota kelompok lainnya. Ia akan memiliki penilaian yang positif akan dirinya jika ia merasa diterima dan menjadi bagian dari kelompok tersebut. Individu akan menilai sebaliknya jika ia merasa 
ditolak atau tidak diterima oleh kelompok tersebut.

b. Feeling of competence, yaitu perasaan individu bahwa ia mampu melakukan sesuatu untuk mencapai hasil yang diharapkan. Jika ia berhasil mencapai tujuan maka ia akan memberikan penilaian positif terhadap dirinya. Selain itu, ia merasa percaya terhadap pikiran, perasaan dan tingkah laku yang berhubungan dengan kehidupannya.

c. Feeling of worth, yaitu perasaan individu bahwa dirinya berharga. Individu yang memiliki perasaan berharga akan menilai dirinya secara positif, merasa yakin terhadap diri sendiri, dan mempunyai harga diri atau self respect.

\section{Pengembangan Harga Diri dalam Islam}

Di antara tujuan penting yang diemban oleh ajaran Islam ialah membangkitkan harga diri manusia pada masa jahiliyah Arab. Masyarakat Arab waktu itu terbagi atas dua golongan besar, yaitu golongan merdeka dan golongan budak, kaya dan miskin, yang kuat dan yang lemah. Harga diri sekelompok masyarakat dianggap begitu rendah, sehingga budak belian tidak dianggap sebagai manusia, tapi diperjualbelikan seperti binatang. Bahkan ibu yang melahirkan bayi perempuan dianggap aib yang luar biasa. Dalam masyarakat seperti itulah Islam datang membawa ajaran yang jelas.Semua manusia sama di sisiNya, bahwa yang tinggi dan agung itu hanyalah Allah swt.

Untuk membangkitkan harga diri manusia, Al-Qur'an menyatakan, 'Kuntum Khaira Ummatin'. "Kamu adalah sebaik-baik umat." (QS. Ali Imran: 110).

Dan dalam al-Qur'an Surat Ali Imran: 139,

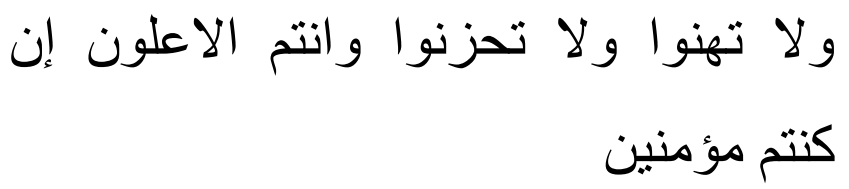

"Janganlah kamu bersikap lemah dan bersedih hati. Padahal kamulah orang yang tinggi (derajatnya) jika kamu orang beriman."

Hal yang dilakukan Rasulullah saw. untuk membangkitkan harga diri umatnya, antara lain adalah saat beliau bersama orang-orang fakir dan miskin. Mereka merupakan kelompok yang sering direndahkan dan dicaci maki. Untuk membangkitkan harga diri mereka, Rasulullah saw. memilih hidup di tengah-tengah mereka, sehingga beliau memperoleh gelar Abul Masakin (bapaknya orang-orang miskin).

Upaya lain yang dilakukan Rasulullah saw.untuk membangkitkan harga diri umatnya, adalah ketika beliau sangat memuliakan anakanak atau kaum perempuan. Beliau bersabda, "Barangsiapa memiliki tiga anak perempuan, lalu ia melindungi mereka, mengasihi mereka, memelihara mereka dengan baik, ia pasti masuk surga". (HR. Bukhari)

Demikianlah, pada saat anak perempuan dipandang rendah, justru Rasulullah saw. memuliakan. Betapa pada saat itu kehadiran anak 
perempuan dianggap bencana, tapi Rasulullah saw. menyebut Fatimah sebagai "Al-Kautsar", yang berarti 'anugerah yang banyak.'

Sementara kepada cucu-cucunya, Hasan dan Husain, beliau berkali-kali mengatakan, "Sesungguhnya Hasan dan Husain adalah pemimpin pemuda ahli surga, ayah mereka lebih baik dari mereka.." Demikian juga, beliau berkata, "Hasan dan Husain adalah penyejuk mataku di dunia."

Itulah beberapa riwayat yang mengisahkan ungkapan-ungkapan Rasulullah saw. dalam rangka menanamkan rasa bangga kepada putri dan cucu-cucunya; yang tentu saja menjadi teladan bagaimana seharusnya menanamkan rasa bangga ke dalam diri anak, agar mereka memiliki harga diriyang tinggi.

Fauzil Adhim (2001:70) menjelaskan bahwa dari kalangan ulama, yaitu Imam Syafi'i, seorang mujtahid mutlak keturunan Rasulullah saw. melalui jalur ibu yang bersambung ke AlHasan bin Ali bin Abu Thalib menasehatkan, "Barangsiapa menasehati saudaranya secara diam-diam, berarti dia telah menasehati dan menginginkan kebaikannya; dan barangsiapa menasehatinya di tempat ramai, maka ia telah membuka rahasianya dan memburukkan namanya."

Dari ungkapan tersebut dapat dilihat betapa ajaran Islam itu sangat menjaga harga diri seseorang. Meskipun seorang anak telah melakukan suatu kesalahan, akan tetapi harga dirinya harus tetap dijaga yaitu dengan menasehatinya secara diam-diam. Karena jika anak dinasehati di depan umum, maka ia akan merasa malu dan harga dirinya pun akan turun.

\section{Peran Orangtua dalam Mengembangkan Harga Diri Anak}

Menurut para psikolog, pengembangan harga diri sangat dipengaruhi oleh pengalaman awal semasa kanak-kanak seseorang. Keluarga sebagai tempat pendidikan pertama memiliki peran dalam proses sosialisasi. Kepribadian seorang anak tergantung pada bagaimana pendidikan yang dibangun di dalamnya. Ketika pendidikan yang diberikan baik, maka sejak dini anak dapat memahami mana hal yang baik atau buruk, yang bisa diterima atau tidak diterima, dan yang boleh dilakukan atau tidak boleh dilakukan. Pendidikan tersebut tidak hanya diajarkan, tapi akan lebih berhasil jika orang tua memberikan contoh secara langsung melalui perbuatan dan kebiasaan sehari-hari. Dan orang tua lah yang menjadi sentral dan role model, akan menjadi seperti apakah seorang anak. Apa yang dilakukan orang tua akan merefleksi balik pada anaknya dalam bentuk citra diri, dan pola asuh orang tua akan mempengaruhi harga diri anak. Orang tua yang berharga diri tinggi cenderung memiliki anak yang berharga diri tinggi, begitu juga sebaliknya.

Pola asuh orang tua yang otoriter, mendidik dengan sifat permusuhan, senang menghukum, dan banyak cacian terhadap anaknya, membentuk anak yang berkepribadian 
murung, rendah diri, serta memendam kebencian dan permusuhan. Demikian juga apabila orang tua mengasuh secara demokratis dan bijaksana, maka akan tumbuh seorang anak yang berkepribadian menyenangkan dan mampu menyesuaikan diri dengn lingkungan. Orangtua yang demokratis cenderung membentuk harga diri anak menjadi tinggi, sementara orang tua yang otoriter dan permisif cenderung membentuk harga diri anak menjadi rendah.

Marzuki (2004: 13-132) berpendapat bahwa orangtua atau pendidik harus memberikan respon positif kepada anak, yang ditunjukkan dengan sikap, perhatian, serta mendengarkan secara aktif terhadap apa yang dikemukakan oleh anak. Apabila orangtua bersikap cuek terhadap apa yang dikemukakan anak, maka hal ini akan membangkitkan perasaan perih pada nuraninya. Anak akhirnya berkesimpulan bahwa pendapatnya tak pantas untuk dikemukakan, sebab dia sendiri menjadi tidak percaya bahwa apa yang dikemukakan ini sesuatu yang berarti, yang berhak didengarkan oleh orang lain. Bahkan berangkat dari perasaan ini akhirnya dia akan berkesimpulan bahwa dirinya tak berharga, orang lain tak ada yang memerlukan, dan keberadaannya tak pernah diperhituungkan.

Harga diri bisa dibangun melalui proses pendisiplinan anak dengan syarat bahwa anak merasa dicintai tanpa syarat. Ariesandi (2008: 263-264) mengemukakan beberapa caranya yaitu dengan memberikan teladan pada anak melalui tindakan orangtua, memperhatikan usia dan perkembangan anak, menggunakan bahasa cinta anak untuk memenuhi tangki emosionalnya, melakukan komunikasi dengan memperhatikan tipe kepribadian anak, serta memahami mekanisme pikiran anak.

Harga diri juga menyangkut perasaan bangga dari anak sebagai hasil dari belajar mengerjakan sesuatu atas usahanya sendiri (Yustinus, 2006: 329). Pada tingkat ini, anak ingin membuat benda-benda, menyelidiki dan memuaskan rasa ingin tahunya tentang lingkungan, memanipulasi, dan mengubah lingkungan itu. Anak yang berusia dua tahun yang bersifat ingin tahu dan agresif dapat menjadi sangat destruktif karena dorongan untuk memanipulasi dan menyelidiki ini menguasai dirinya. Apabila orang tua menghalangi kebutuhan anak untuk menyelidiki, maka perasaan harga diri yang muncul dapat rusak. Akibatnya dapat muncul perasaan dihina dan marah.

Berkaitan dengan peran orangtua dalam mencintai anaknya, harga diri juga dapat diartikan sebagai kombinasi dari perasaan mampu dan perasaan dicintai. Anak yang mencapai suatu keberhasilan tapi merasa tidak dicintai akan memiliki harga diri yang rendah. Sebaliknya, anak yang merasa dicintai tapi merasa kurang mampu juga akan memiliki harga diri rendah. Jadi harga diri yang sehat merupakan hasil dari keseimbangan dari keduanya.

Sebuah penelitian mengungkapkan bahwa anak mendasari harga diri mereka pada 
dua hal, yaitu penerimaan (sejauh mana lingkungan khususnya orangtua menerima mereka apa adanya) dan kompetensi diri seperti "Aku pandai" atau "aku bisa lari kencang" (Hildebrand, 1985). Penelitian ini juga menemukan bahwa kebanyakan anak yang punya harga diri positif ternyata memiliki orangtua dengan karakteristik yang sama, yaitu juga punya harga diri yang positif tentang diri mereka sebagai orangtua.

Berikut beberapa sisi perilaku orangtua yang dapat membentuk harga diri positif pada anak:

a. Mutu perilaku dan performa tinggi dari orangtua

b. Menerapkan batas-batas yang jelas mana perilaku yang boleh dan mana yang tidak dilakukan

c. Bimbingan perilaku dan umpan balik dari orangtua

d. Memperlakukan anak dengan respek dan kepercayaan diri

e. Memberi perhatian dan terlibat dalam kegiatan akademik dan sosial anak

f. Pendekatan yang tidak memaksa untuk membentuk disiplin anak

g. Memperlakukan anak secara demokratis

\section{Strategi Mengembangkan Harga Diri Anak}

Pada masa sekarang ini terlalu banyak anak yang tumbuh dan berkembang dengan menerima pujian yang kosong, dan karenanya memiliki harga diriyang semu. Mereka terlalu sering menerima pujian untuk prestasi yang biasa saja atau bahkan jelek. Mereka akan sulit untuk berkompetisi atau menerima kritik. Ada beberapa cara yang baik untuk meningkatkan harga dirianak yaitu: (1) identifikasi domain kompetensi yang dianggap penting bagi anak, (2) dukungan emosional dan persetujuan sosial, (3) prestasi, (4) coping. (Santrock, 2007: 67)

Harter dalam Santrock (2007: 67) menyatakan percaya bahwa intervensi harus diberikan pada penyebab harga dirijika kita menginginkan seseorang mengalami peningkatan harga diriyang signifikan. Anak akan memiliki harga diritertinggi ketika mereka dapat tampil dengan kompeten di domain yang dianggap penting bagi mereka. Karena itu anak harus didorong untuk mengidentifikasi dan menghargai arena dimana mereka bisa tampil kompeten.

Dukungan emosional dan persetujuan sosial juga merupakan hal yang bisa mempengaruhi harga dirianak. Beberapa anak yang memiliki harga diriyang rendah ternyata berasal dari keluarga bermasalah atau pernah mengalami kekerasan atau ditelantarkan-situasi dimana tidak ada dukungan emosional. Bagi beberapa anak, program formal seperti kakak asuh dapat menjadi sumber alternatif dukungan sosial dan persetujuan sosial; bagi anak yang lain, dukungan ini bisa juga diperoleh dari sumber informal seperti guru, pelatih olahraga, atau orang dewasa lain. 
Santrock (2007: 68) berpendapat bahwa harga diriakan meningkat ketika anak menghadapi masalah dan mencoba mengatasinya daripada menghindarinya. Jika anak tetap memilih menghadapi masalah daripada menghindarinya, anak akan bersikap realistis, jujur, dan tidak defensif. Hal ini akan menghasilkan evaluasi diri yang baik, yang akan menghasilkan persetujuan diri yang pada akhirnya meningkatkan harga diri. Hal sebaliknya akan terjadi untuk harga diriyang rendah; evaluasi diri yang buruk akan membuat anak melakukan penyangkalan, menipu diri, lari dari masalah, yang pada akhirnya akan menghasilkan ketidaksetujuan diri.

Menurut Branden (2005: 54) terdapat dua aspek yang dapat menghambat perkembangan harga diri, yaitu perasaan takut dan perasaan bersalah. Perasaan takut muncul ketika anak tidak mampu menghadapi fakta-fakta kehidupan dengan penuh keberanian. Fakta-fakta tersebut merupakan tanggapan negatif terhadap diri yang menjadikan anak hidup dalam ketakutan. Aspek kedua yang menghambat harga diri adalah perasaan bersalah yang mencakup perasaan bersalah karena melanggar nilai-nilai moral. Anak menghayati kesalahan sebagai sebuah pelanggaran terhadap nilai kehidupan yang telah ditanamkan dalam diri oleh orang yang menguasainya, yaitu seseorang yang dianggap berharga dan ditakuti.

Kontrol emosi negatif yang muncul merupakan salah satu aspek perkembangan emosionalpada anak. Secara bertahap, anak anak belajar tentang apa yang membuat takut, bersalah, marah, atau sedih, dan begaimana orang lain bereaksi dalam menunjukkan emosi ini, dan mereka mengadaptasikan perilaku mereka dengan emosi-emosi tersebut. Anak juga mempelajari perbedaan antar emosi dan bagaimana mengekspresikannya.

Usahakan anak mengalami perasaan positif dalam empat kondisi mental berikut: (1) Rasa Terikat; anak merasa adanya kepuasan bathin dalam hubungannya dengan orang tua dan keluarganya sehingga menimbulkan rasa keterikatan, (2) Rasa Unik; anak merasa dirinya spesial. Ia menghargai sifat tertentu yang membuatnya istimewa ketika ia menerima penghargaan atau pengakuan dari orang lain, (3) Rasa berkuasa; perasaan yang bersumber dari memiliki sumber daya dan kemampuan untuk mempengaruhi lungkungannya, (4) Model; contoh perilaku individu, falsafah, dan tindakan yang menjadi model untuk mewujudkan nilainilai, cita-cita dan tolok ukur pribadi. Untuk membuat harga diri tinggi, keempat kondisi tersebut harus hadir secara terus menerus. Jika salah satu kondisi itu tidak cukup tersedia, akan berakibat gangguan terhadap harga diri.

Beberapa strategi untuk meningkatkan harga diri anak, adalah:

a. Hati-hati dengan ucapan. Anak sangat sensitif terhadap apa yang dikatakan orangtuanya, apalagi jika dikatakan berulang-ulang sampai diyakini oleh anak. Jadi hati-hati, apa yang 
orangtua katakan seolah seperti pesan yang akan terprogram dalam diri anak. Hindari kata-kata seperti "Ah, payah kamu!"

b. Hindari membicarakan hal yang kurang baik menyangkut diri anak di hadapan anak tersebut. Apa yang ia dengar akan mempengaruhi persepsi diri anak.

c. Puji usahanya meskipun belum membawa hasil. Contoh, katakan "Bunda bangga kamu sudah berusaha keras" bukan "Kalau kamu lebih berusaha, pasti bisa." Ucapkan dengan tulus dan tujukan khusus untuk anak sehingga anak merasa benar-benar dihargai dan diperhatikan.

d. Hindari memuji terlalu berlebihan karena akan mengaburkan penilaian anak tentang kesuksesan dan sulit baginya untuk melihat kelebihan serta kekurangan dirinya yang sebenarnya. Anak yang biasa mendengar pujian "Kamu anak paling hebat di kelas" akan membentuk harapan yang kurang realistis dan rasa takut gagal. Anak akan mengasosiasikan untuk dicintai atau diperhatikan, dia harus selalu menjadi yang paling hebat.

e. Ketika anak berhasil mencapai sesuatu, buatlah dia merasa keberhasilan tersebut untuk dirinya sendiri bukan untuk menyenangkan hati orang lain. Misalnya, "Wow, bagus sekali gambarmu. Pasti kamu bangga sekali!" bukan "Bagus, Papa senang punya anak seperti kamu." f. Lakukan hal-hal spontan yang membuat anak merasa dicintai, misalnya berikan pelukan pada anak.

g. Berikan tauladan yang baik. Sebagai orangtua juga perlu memberikan contoh yang mencerminkan harga diri yang sehat seperti bersikap optimis dan tidak mudah menyerah.

h. Deteksi dan alihkan pemikiran negatif anak. Contoh, anak mengatakan "Aku tidak bisa main puzzle", orangtua dapat mengalihkannya dengan mengatakan "Wah kamu kan anak pintar, pasti bisa. Puzzle memang agak lama menyelesaikannya. Ayo, kita kerjakan samasama, yuk!”

i. Buatlah suasana rumah seaman dan senyaman mungkin bagi anak. Hindari pertengkaran di depan anak atau memberikan hukuman fisik pada anak. Di rumah, anak sepatutnya juga merasa dihargai haknya selain dicintai.

j. Berikan kesempatan memilih pada anak dan hargailah pilihannya. Contoh, anak diberi kesempatan untuk memilih baju yang akan dipakai bepergian. Jika orangtua cemas akan pilihannya nanti kurang sesuai, orangtua dapat membatasi item pilihannya terlebih dahulu.

k. Jeli dan cepat atasi jika anak mengalami masalah di luar rumah, misalnya diejek teman di sekolah. Beri penguatan pada anak dan bicarakan masalah ini dengan pihak sekolah jika sudah sangat mempengaruhi anak.

1. Tetapkan harapan realistis pada anak, sesuai dengan tahapan perkembangannya. Misalnya tidak menuntut anak untuk segera bisa baca 
tulis di usia 4 tahun. Dengan menyesuaikan harapan dengan kemampuan anak akan memperbesar kemungkinan anak untuk mengalami keberhasilan yang penting untuk meningkatkan harga dirinya. Namun di sisi lain, orangtua juga harus tahu kapan harapan bisa ditingkatkan seiring dengan bertambahnya usia anak. Ini berguna untuk memacu anak meningkatkan kemampuannya tapi tetap harus berpedoman pada kesiapan anak. Misalnya anak mulai tertarik pada buku, tidak ada salahnya orangtua mulai mengenalkannya pada huruf tapi dengan cara bermain dan tanpa paksaan.

m. Hindari suasana kompetisi di rumah. Contoh kompetisi siapa yang lebih cepat menghabiskan makanan. Jika ini menjadi kebiasaan dan si bungsu terus menerus kalah, maka akan terbentuk penilaian diri yang kurang baik.

n. Kenali kemampuan anak sehingga orangtua dapat merefleksikannya pada anak. Contoh, ketika anak bilang tidak bisa pakai kaus kaki, orangtua dapat mengatakan "Susah ya pakai kaus kakinya...tapi lihat kamu sudah bisa pakai baju dan celana sendiri!”

o. Hargai inisiatif anak meski belum membawa hasil yang sempurna. Contoh, "Wah rajin sekali anak Mama, mau merapikan mainan sendiri" bukan "Wah kok merapikannya asalasalan...jadinya harus Mama rapikan lagi deh." p. Mengembangkan kemandirian anak. Hindari anak dibiasakan untuk selalu dilayani atau dibantu dalam melakukan hal-hal yang sebenarnya sudah bisa ia lakukan sendiri.

q. Apabila anak menunjukkan harga diri yang rendah, orangtua juga dapat minta bantuan dari psikolog anak untuk bersama-sama menemukan dan mengatasi rintangan apa yang membuat anak berpandangan negatif tentang dirinya.

\section{Implementasi Pengembangan Harga Diri Anak pada Pembelajaran}

$$
\text { Tony Wagner }
$$

mengemukakantentang tujuh kemampuan yang harus dimiliki anak di masa depan, yaitu terampil berpikir kritis dan memecahkan masalah, kolaborasi berbasis jaringan dan mengembangkan kemampuan memimpin yang berpengaruh, mampu mengubah arah dan bergerak secara cepat, efektif, dan beradaptasi, memiliki daya inisiatif dan berkewirausahaan, bicara dan menulis secara efektif, mengakses dan menganalisis informasi, dan bersikap selalu ingin tahu dan berimajinasi.

Dalam tulisan tersebut Tony Wagner mengajak para pendidik untuk selalu mengingat peran pentingnya dalam menanamkan nilai kepada anak. Hal tersebut dapat dimulai dengan menjadikan guru sebagai contoh yang baik (role models) bagi anak.Langkah berikutnya adalah memberikan ruang pengembangan minat dan bakat pada anak. Guru melakukan habituasi atau 
pembiasaan dengan berperan sebagai fasilitator dan memonitoring penerapan nilai oleh anak. Apabila pembiasaan telah dilakukan dengan baik, maka perlu adanya kontinuitas agar nilai dapat terinternalisasi dalam diri anak.

Dalam membentuk harga diri anak, orangtua memiliki peran yang dominan. Akan tetapi dalam pembelajaran di sekolah guru juga memiliki peran dalam beberapa hal mendasar. Peran tersebut adalah menemukan kemampuan unik anak, mengapresiasi prestasi dan hasil kerja anak, memuji anak dengan spesifik, dan menonjolkan sisi positif anak.

Pada proses pembelajaran secara umum, untuk mengembangkan harga diripada anak, guru dapat melakukan langkah-langkah sebagai berikut:

a. Menunjukkan proses pencapaian prestasi belajar kepada anak. Hal ini bisa dilakukan guru dengan menggunakan alat-alat sederhana, seperti gambar diagram pada kertas, kartu kompetensi anak yang memuat informasi proses pencapaian kompetensi anak, dll. Adanya bukti-bukti ini akan memberikan gambaran pada diri anak betapa mereka mengalami perkembangan kemampuan dari waktu ke waktu. Tidak hanya itu, menunjukkan hasil tugas juga bisa bermakna sangat banyak pada diri anak. Selain mengetahui kemampuannya, mereka juga dapat memberikan penilaian terhadap dirinya sendiri secara keseluruhan. b. Mengungkapkan tanggapan berupa pujian pada anak yang mampu melakukan sesuatu, dan memberikan dorongan ketika anak gagal melakukan sesuatu. Tanggapan juga tidak sekedar pujian, namun dapat berupa tindakan.

c. Menolong anak yang mengalami hambatan. Berikan contoh-contoh yang membangkitkan semangat anak, misal tentang perjuangan tokoh atau ilmuwan.

d. Melatih anak untuk membuat pernyataan positif mengenai dirinya.

e. Tidak memberikan kritik yang membuat anak merasa dipermalukan.

f. Mengajarkan anak agar mampu mengambil keputusan akan sesuatu dan tindak lanjuti dengan mengajarkan tentang mengenali apakah keputusannya itu baik atau justru sebaliknya.

g. Membangun struktur diri pada anak melalui pendekatan positif. Dalam hal ini terdapat pemberian tanggungjawab dan penumbuhan kedisiplinan.

\section{KESIMPULAN}

Pembentukan harga diri merupakan sebuah proses yang berkesinambungan. Harga diri yang telah terbentuk pada usia dini akan memberikan pengaruh yang sangat signifikan terhadap perilaku kehidupan anak di kemudian hari. Langkah-langkah nyata dan penggunaan strategi yang tepat perlu dilakukan guru dan pihak sekolah dalam rangka menuangkan pengembangan harga diri anak dalam proses 
pembelajaran. Harus disadari bahwa tumbuhnya perhargaan terhadap diri tidak terlepas dari bagaimana orang lain menghargai diri anak. Sedemikian pentingnya pengembangan harga diri bagi setiap individu, maka perlu adanya kerjasama yang sinergis antara guru di sekolah dan orangtua.

\section{DAFTAR PUSTAKA}

Adhim, M. Fauzil. (2001). Bersikap Terhadap Anak. Yogyakarta: Titian Ilahi Press.

Al-Qur'an dan Terjemahan. (2012). Jakarta: PT Khazanah Mimbar Plus

Ariesandi S. (2008). Rahasia Mendidik Anak Agar Sukses dan Bahagia, Jakarta: PT Gramedia Pustaka Utama.

Branden N. (2005). The Power of Self-Esteem. New York: Bantam.

Burns RB. (1993). Konsep Diri: Teori, Pengukuran, Perkembangan dan Perilaku. Jakarta: Arcan.

Coopersmith, S. (1967). The Antecedents of Self Esteem. San Francisco, California: W.H. Freemen and Co.

Felker, D.W.(1974). Helping children to like themselves. Minneapolis: Burgess Publishing Company.

Johnson ,D.W. \&Johnson, F.P. (1991). Joining Together: Group Theory \& Group Skills, $\left(4^{\text {th }}\right.$ Edition). New York: Prentice-Hall, Inc.

Marzuki, A. Choiran. (2004). Anak Saleh dalam Asuhan Ibu Muslimah. Yogyakarta: Mitra Pustaka.

Musbikin, Imam. (2004). Mendidik Anak Ala Shinchan. Yogyakarta: Mitra Pustaka.
Papalia, E.Diane dkk. (2008). Human Development. Jakarta: Kencana,. $9^{\text {th }}$ edition

Papalia Olds Feldman. (2009). Human Development. Jakarta: Salemba Humanika.

Phelan, W. Thomas. (2009). 1-2-3 Magic, Cara Ajaib Mendisiplinkan Anak Umur 2-12 Tahun. Yogyakarta: Penerbit ANDI.

Santrock, John W. (2007). Perkembangan Anak. Jakarta: Penerbit Erlangga,

Stuart \&Sundeen. (1991). Principle and Practice of Psychiatric Nursing. St. Louis: Mosty Company

Wagner, Tony. (2008).The Global Achievement Gap: Why Even Our Best Schools Don't Teach the New Survival Skills Our Children Need-and What We Can Do About It. New York: Basic Books

Verna Hildebrand. (1985). Guiding Your Children. Macmillan: Collier Macmillan Publishers.

Yustinus Semiun, OFM., (2006). Kesehatan Mental: Pandangan Umum Mengenai Penyesuaian Diri dan Kesehatan Mental serta Teori-teori yang Terkait. Yogyakarta: Penerbit Kanisius 